Reprod. Nutr. Dévelop., 1985, 25 (1 B), 175-181.

\title{
Factors controlling brown adipose tissue development
}

\author{
D. RICQUIER, G. MORY, F. BOUILLAUD, Michèle COMBES-GEORGE, \\ J. THIBAULT (*)
}

with the technical assistance of Christine BLANCHARD

Laboratoire de Physiologie comparée (L.A. 307, CNRS), Université $P$. et $M$. Curie, 4, place Jussieu, 75230 Paris Cedex 05, France and

(*) Collège de France.

\begin{abstract}
Summary. Brown adipose tissue (BAT) is a site of non-shivering thermogenesis in mammals. Thermogenesis in brown adipocytes is related to the presence of a specific mitochondrial component called " uncoupling protein ". When animals are chronically exposed to cold, their BAT is enlarged and exhibits several changes such as cellular differentiation, hyperplasia, mitochondriogenesis and marked synthesis of uncoupling protein. The hormonal and neural factors controlling this adaptive response have been studied. It is concluded that sympathetic innervation of BAT and released noradrenaline play an essential role in the development of BAT.
\end{abstract}

\section{Introduction.}

Brown adipose tissue (BAT) is the only known tissue whose main function is heat production. BAT is an important site of non-shivering thermogenesis and perhaps of diet-induced thermogenesis. BAT, existing in most mammals where it accounts for 0.5 to $5 \%$ of the body weight, has been well characterized in human newborns (Hull and Hardman, 1970 ; Lean and James, 1983), but the question of its physiological importance in adult humans is not yet known. BAT contains brown adipocytes characterized by many small multilocular triglyceride droplets and a rare high content of mitochondria with packed cristae. Brown adipocytes are also directly innervated by sympathetic fibres containing noradrenaline.

Thermogenesis in brown adipocytes mainly results from the physiological uncoupling of oxidative phosphorylation. This uncoupling mechanism involves the specific, regulated transport of protons across the inner membrane (see review by Nicholls and Locke, 1984). The molecular basis for this conductance pathway is a 
specific $32000 \mathrm{M}_{\mathrm{r}}$ protein called " uncoupling protein " located in the inner mitochondrial membrane (see reviews by Girardier, 1983 ; Nicholls and Locke, 1984 ; Cannon and Nedergaard, 1984). During acute exposure to cold, noradrenaline is released which binds to adrenoreceptors coupled to the adenylate cyclase system. Subsequently, lipolysis is stimulated and fatty acids are oxidized into mitochondria. When animals are chronically exposed to cold, their BAT exhibits a marked development which is an adaptive response allowing the tissue to increase its thermogenic capacity. Such BAT development is due to the proliferation and maturation of endothelial precursor cells and leads to a doubling or tripling of the DNA content (see review by Barnard, Mory and Nechad, 1980). Concomitantly, total and mitochondrial protein and phospholipid contents are increased, the fatty acid composition of phospholipid is altered, and the proportion of uncoupling protein is strikingly elevated (see reviews by Girardier, 1983 ; Ricquier and Mory, 1984). The thermogenic activity of BAT is roughly proportional to the amount of uncoupling protein (Ricquier and Kader, 1976 ; see review by Nicholls and Locke, 1984). Thus, factors which modulate the level of uncoupling protein also control the development and activity of BAT. The factors controlling BAT development have been studied and classed as hormonal or neural.

\section{Material and methods.}

Treatments used on rats. - Sprague-Dawley, Wistar or New England Deaconess Hospital rats were either kept at room temperature or at $5{ }^{\circ} \mathrm{C}$. Hyperthyroid rats were injected daily with $L-T_{4}$ (Ricquier, Mory and Hemon, 1976). The animals receiving methymazole were made hypothyroid (Mory et al., 1981). Streptozotocindiabetic rats and hyperinsulinemic rats were obtained as described by Seydoux et al. (1984). The catecholamine treatments used in the rats have been described by Mory, Ricquier and Hemon (1980) and by Mory et al. (1984). Rats bearing phaeochromocytomas (PC 12 cell line) have been described by Ricquier et al. (1983a).

Tissue sampling of human patients. - BAT was collected from the perirenal and periadrenal areas of patients with phaeochromocytomas (Ricquier, Nechad and Mory, 1982). White adipose tissue was collected from other patients.

Biochemical determinations and morphological study. - Tissue analysis and the determination of uncoupling protein have been reported by Ricquier, Mory and Hemon (1976), Ricquier and Kader (1976) and Ricquier, Nechad and Mory (1982). The histological procedures have been described by Ricquier, Nechad and Mory (1982).

\section{Results and discussion.}

1. Hormonal factors controlling BAT development.

1.1. Thyroid hormones. - Thyroid hormones, which stimulate thermogenesis and are necessary for survival in the cold, are good candidates for 
the control of BAT development. A comparison of hyperthyroid and coldacclimated rats has clearly demonstrated that injections of $T_{4}$ do not mimic the effects of prolonged exposure to cold. The enlargement of BAT in hyperthyroid rats is merely due to an increase in the triglyceride content (see review by Ricquier and Mory, 1984). Not only has chronic treatment with thyroid hormones failed to mimic the effects of acclimation on BAT growth, but injection of $T_{4}$ in rats acclimated to cold prevented normal cold-induced changes from occurring in BAT (Ricquier, Mory and Hemon, 1976 ; see review by Barnard, Mory and Nechad, 1980). It has been reported recently that chronic treatment with $\mathrm{T}_{4}$ decreases the level of uncoupling protein (Sundin, 1981 ; Triandafillou. Gwilliam and Himms-Hagen, 1982).

Studies carried out in hypothyroid animals have reported that their tissue composition is almost similar to that observed in cold-acclimated rats (Mory et al., 1981). The role of thyroid hormones in the development of BAT can be restricted to a permissive one. BAT is not a target of thyroid-stimulated thermogenesis.

1.2. Insulin. - Insulin has obvious metabolic effects on BAT which are similar in many ways to those observed in white adipose tissue (see review in Ricquier and Mory, 1984).

In collaboration with J. Seydoux, E. Trimble, F. Assimacopoulos-Jeannet, J. P. Giacobino and L. Girardier, we have studied the BAT of streptozotocindiabetic rats and of those chronically infused with insulin. We found that insulin increased the BAT mass, the metabolic capacity of the tissue, and the concentration of uncoupling protein in BAT mitochondria (Seydoux et al., 1984). Nevertheless, these effects of insulin on BAT were probably both direct (effects on the tissue) and indirect (via activation of the ventromedial hypothalamic nucleus which, in turn, activates the sympathetic fibres innervating BAT) (see discussion by Ricquier and Mory, 1984).

\section{Neural factors controlling BAT development.}

2.1. The role of neural factors in response to chronic cold exposure. - Since sympathetic activity is generally stimulated when animals are exposed to cold (Jansky, 1973), we examined the role of BAT sympathetic innervation in the trophic response of this tissue during the prolonged exposure of rats to cold.

It was first observed that sympathectomy suppressed the major aspects of the trophic response of BAT in the cold-acclimated rats; there was no increase in DNA, total and mitochondrial protein and the proportion of uncoupling protein, and no alterations in phospholipids (Mory et al., 1982). Daily injections of noradrenaline or of isoproterenol for three weeks can induce the growth of BAT, including hyperplasia, increased protein content and cytochrome $\mathrm{C}$ oxidase activity (see review by Ricquier and Mory, 1984). However, in these conditions, the increase in mitochondrial uncoupling protein was not observed (Desautels and Himms-Hagen, 1979 ; Mory, Ricquier and Hemon, 1980), suggesting that noradrenaline and sympathetic innervation of BAT were necessary, but not sufficient, to induce the complete development of BAT. Nevertheless, recent investigations, in which noradrenaline was continuously infused to rats through 
mini-osmotic pumps, showed that the BAT of noradrenaline-infused rats developed in a way similar to that observed in cold-acclimated rats (Mory et al., 1984). These data lead us to propose that noradrenaline released by nerve endings in the BAT is the mediator of the adaptive development of that tissue. This proposition is in excellent agreement with recent data by Young, Wilson and Arch (1984) who chronically stimulated BAT with $\beta$-agonists.

2.2. The effects of phaeochromocytomas in animals and humans. - The development of BAT and BAT pseudotumors has been described in animals and humans bearing phaeochromocytomas which are tumors secreting large amounts of catecholamines (see review by Girardier, 1983).

The development of phaeochromocytomas in rats induced BAT to develop and stimulated synthesis of the uncoupling protein (Ricquier et al., 1983b ; Bouillaud et al., 1984). A study of the perirenal fat of humans bearing phaeochromocytomas revealed that this fat was typical BAT (Ricquier, Nechad and Mory, 1982 ; Bouillaud, Combes-George and Ricquier, 1983). Thus, sympathetic factors released by tumorous chromaffin cells are able to induce the maturation of precursor cells and/or the dedifferentiation of unilocular fat cells. These data are in excellent agreement with those obtained by chronic delivery of noradrenaline to rats. In both conditions the level of uncoupling protein was markedly increased.

The major effects induced by catecholamine injections or observed in the presence of phaeochromocytomas are listed on table 1.

\section{Conclusion.}

The action of thyroid hormones in the development of BAT during prolonged stimulation of that tissue can probably be restricted to a permissive action. Insulin can stimulate (directly and/or indirectly) the development of BAT. The innervation of BAT plays an essential role in its development. It is proposed that noradrenaline released by nerve endings in BAT is not only the major mediator of thermogenesis in BAT but that it is also the factor controlling the development of that tissue.

$10^{e}$ Reunion du groupe Développement I.N.R.A., Rennes, 9-10 mai 1984.

Acknowledgements. - This work was financially supported by C.N.R.S.

Résumé. Facteurs contrôlant le développement du tissu adipeux brun.

Le tissu adipeux brun (TAB) est un organe thermogénique important chez beaucoup de mammifères. II permet la production de chaleur lors de l'exposition au froid et dans certaines conditions d'alimentation. Les mitochondries du TAB contiennent une protéine spécifique, la protéine découplante, qui leur permet de dissiper l'énergie des oxydations sous forme de chaleur. Lorsque des animaux sont adaptés au froid, le TAB se développe. Ce phénomène est caractérisé par une différenciation cellulaire, une hyperplasie, une mitochondriogenèse et une synthèse de protéine découplante. Les hormones thyroïdiennes ne 


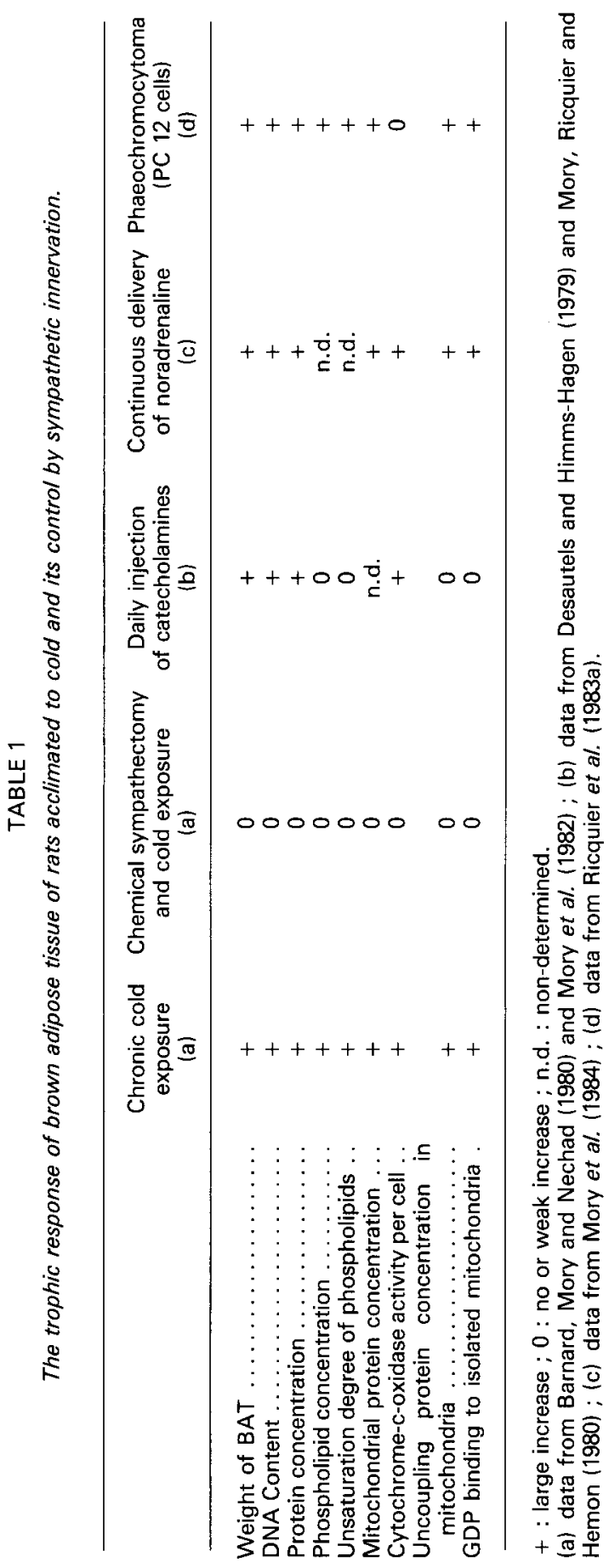


jouent pas un rôle essentiel dans la croissance du TAB. Plusieurs approches ont été utilisées afin d'étudier le rôle de l'innervation orthosympathique du TAB dans le développement du tissu : sympathectomie, injections de $\beta$-agonistes ou de $\beta$-bloquants, présence de phéochromocytomes (rat et homme), perfusion chronique de noradrénaline. L'ensemble des résultats obtenus montre que la noradrénaline libérée par les terminaisons nerveuses, outre son rôle dans l'activation métabolique, joue un rôle essentiel dans le développement de la capacité thermogénique du TAB.

\section{Références}

BARNARD T., MORY G., NECHAD M., 1980. Biogenic amines and the trophic response of brown adipose tissue, 391-439. In PARVEZ S., PARVEZ H., Biogenic amines in development, Elsevier, Amsterdam.

BOUILLAUD F., COMBES-GEORGE M., RICQUIER D., 1983. Mitochondria of adult human brown adipose tissue contain a 32,000-M uncoupling protein. Biosci. Rep., 3, 775-780.

BOUILLAUD F., RICOUIER D., MORY G., THIBAULT J., 1984. Increased level of mRNA for the uncoupling protein in brown adipose tissue of rats during thermogenesis induced by coldexposure or norepinephrine infusion. J. biol. Chem., 259, 11583-11586.

CANNON B., NEDERGAARD J., 1984. The biochemistry of an inefficient tissue : brown adipose tissue. Assays Biochem., 20, 110-164.

DESAUTELS M., HIMMS-HAGEN J., 1979. Roles of noradrenaline and protein synthesis in the cold-induced increase in purine nucleotide binding by rat brown adipose tissue mitochondria. Can. J. Biochem., 56, 378-383.

GIRARDIER L., 1983. Brown fat: an energy-dissipating tissue, 50-98. In GIRARDIER L., STOCK M. J., Mammalian thermogenesis, Chapman and Hall, London.

HULL D., HARDMAN M. J., 1970. Brown adipose tissue in newborn mammals, 97-115. In LINDBERG O., Brown adipose tissue, Elsevier, New York.

JANSKY L., 1973. Non-shivering thermogenesis and its thermoregulatory significance. Biol. Rev., 48, 85-132.

LEAN M. E. J., JAMES W. P. T., 1983. Uncoupling protein in human brown adipose tissue mitochondria. Isolation and detection by specific antiserum. FEBS Lett., 163, 235-240.

MORY G., BOUILLAUD F., COMBES-GEORGE M., RICQUIER D., 1984. Noradrenaline controls the concentration of the uncoupling protein in brown adipose tissue. FEBS Lett., 166, 393-396.

MORY G., RICQUIER D., HEMON P., 1980. Effects of chronic treatments upon the brown adipose tissue of rats. II. Comparison between the effects of catecholamine injections and cold adaptation. J. Physiol., 76, 859-864.

MORY G., RICQUIER D., NECHAD M., HEMON P., 1982. Impairment of trophic response of brown fat to cold in guanethidine-treated rats. Am. J. Physiol., 242, C159-C165.

MORY G., RICQUIER D., PESQUIES P., HEMON P., 1981. Effects of hypothyroidism on the brown adipose tissue of adult rats : comparison with the effects of adaptation to cold. $J$. Endocr., 91, 515-524.

NICHOLLS D. and LOCKE R., 1984. Thermogenic mechanisms in brown fat. Physiol. Rev., 64, $1-64$.

RICQUIER D., KADER J.-C., 1976. Mitochondrial protein alteration in active brown fat. A sodium dodecyl sulfatepolyacrylamide gel electrophoretic study. Biochem. biophys. Res. Comm., 73, 577-583.

RICQUIER D., MORY G., 1984. Factors affecting brown adipose tissue activity in animals and man, 501-520. In JAMES W. P. T., Clinics in endocrinology and metabolism, Vol. 13-3, Saunders, Epsom.

RICQUIER D., MORY G., HEMON P., 1976. Effects of chronic treatments upon the brown adipose tissue of young rats. I. Cold exposure and hyperthyroidism. Pflugers Arch., 362, 241-246. 
RICQUIER D., MORY G., NECHAD M., COMBES-GEORGE M., THIBAULT J., 1983a. Development and activation of brown fat in rats with pheochromocytoma PC 12 tumors. Am. J. Physiol., 245, C172-C177.

RICQUIER D., NECHAD M., MORY G., 1982. Ultrastructural and biochemical characterization of human brown adipose tissue in pheochromocytoma. J. clin. Endocr. Metab., 54, 803-807.

RICQUIER D., THIBAULT J., BOUILLAUD F., KUSTER Y., 1983b. Molecular approach to thermogenesis in brown adipose tissue. Cell-free translation of mRNA and characterization of the mitochondrial uncoupling protein. J. biol. Chem., 258, 6675-6677.

SEYDOUX J., TRIMBLE E. R., BOUILLAUD F., ASSIMACOPOULOS-JEANNET F., BAS S., RICQUIER D., GIACOBINO J.-P., GIRARDIER L., 1984. Modulation of $\beta$-oxidation and proton conductance pathway of brown adipose tissue in hypo- and hyperinsulinemic states. FEBS Lett., 166, 141-145.

SUNDIN U., 1981. GDP binding to rat brown fat mitochondria : effects of thyroxine at different ambient temperatures. Am. J. Physiol., 241, C134-C139.

TRIANDAFILLOU J., GWILLIAM C., HIMMS-HAGEN J., 1982. Role of thyroid hormone in coldinduced changes in rat brown adipose tissue mitochondria. Can. J. Biochem., 60, 530-537.

YOUNG P., WILSON S., ARCH J. R. S., 1984. Prolonged $\beta$-adrenoreceptor stimulation increases the amount of GDP-binding protein in brown adipose tissue mitochondria. Life Sci., 34, 11111117. 